\title{
Implantable cardioverter-defibrillators in the elderly: rationale and specific age-related considerations
}

\section{Sérgio Barra ${ }^{1 *}$, Rui Providência ${ }^{2}$, Luís Paiva ${ }^{3}$, Patrick Heck $^{\mathbf{1}}$, and Sharad Agarwal ${ }^{1}$}

${ }^{1}$ Cardiology Department, Papworth Hospital NHS Foundation Trust, Papworth Everard, Cambridge CB23 3RE, UK; ${ }^{2}$ Cardiology Department, University College London Hospitals NHS Foundation Trust, London, UK; and ${ }^{3}$ Cardiology Department, Coimbra Hospital and University Centre, Coimbra, Portugal

Received 13 July 2014; accepted after revision 29 September 2014; online publish-ahead-of-print 5 December 2014

Despite the increasingly high rate of implantation of cardioverter-defibrillators (ICD) in elderly patients, data supporting their clinical and costeffectiveness in this age stratum are ambiguous and contradictory. We comprehensively reviewed the state-of-the-art data regarding the applicability, safety, clinical- and cost-effectiveness of the ICD in elderly patients, and analysed which patients in this age stratum are more likely to get a survival benefit from this therapy. Although peri-procedural risk may be slightly higher in the elderly, this procedure is still relatively safe in this age group. In terms of correcting potentially life-threatening arrhythmias, the effectiveness of ICD therapy is comparable in older and younger individuals. However, the assumption of persistent ICD benefit in the elderly population is questionable, as any advantage of the device on arrhythmic death may be largely attenuated by a higher total non-arrhythmic mortality. While septuagenarians and octogenarians have higher annual all-cause mortality rates, ICD therapy may remain effective in highly selected patients at high risk of arrhythmic death and with minimum comorbidities despite advanced age. ICD intervention among the elderly, as a group, may not be cost-effective, but the procedure may reach cost-effectiveness in those expected to live $>5-7$ years after implantation. Biological age rather than chronological age per se should be the decisive factor in making a decision on ICD selection for survival benefit.

Keywords Implantable cardioverter-defibrillator $\bullet$ Elderly $\bullet$ Survival $\bullet$ Safety $\bullet$ Clinical effectiveness $\bullet$ Cost-effectiveness $\bullet$ Risk stratification • Arrhythmia • Sudden death

\section{Introduction}

Implantable cardioverter-defibrillators (ICDs) are a well-established therapy for the prevention of sudden cardiac death (SCD). ${ }^{1-7}$ Studies have shown that $>40 \%$ of ICDs and cardiac resynchronization therapy (CRT) devices are inserted in individuals $\geq 70$ years of age ${ }^{8}$ and $\sim 28 \%$ of those deemed eligible for ICD implantation by conventional criteria are octogenarians. ${ }^{9}$ As the population ages, ${ }^{10,11}$ the number of elderly patients considered for ICD implantation is decidedly increasing. However, data supporting the clinical effectiveness of the ICD in this age stratum are ambiguous and sometimes contradictory. $2,12-18$ Although guidelines state that ICD implantation is 'rarely appropriate' in nonagenarians, ${ }^{19}$ they do not refer to any specific age limits, but rather to 1-year life expectancy as a mandatory criterion. Octogenarians in particular constitute an understudied segment of those potentially eligible for ICD implantation. The few elderly patients selected for admission into large randomized clinical trials are not usually representative of the real-world elderly population.
We aimed to comprehensively review the current literature regarding the potential benefit of ICDs in the elderly and very elderly population. The applicability of ICD utilization in this age group, its safety, clinical effectiveness, and cost-effectiveness will be thoroughly addressed.

\section{Search strategy}

We performed a comprehensive review of scientific data collectable from MEDLINE, EMBASE, and COCHRANE (from inception to May 2014). Studies were selected when addressing the goals of our review: applicability, safety, clinical, and cost-effectiveness of ICD implantation in elderly ( $>70-75$ years old) and very elderly ( $>80$ years old) patients. Qualitative information was extracted and the reference lists of the accessed full-text articles were further evaluated for sources of potential information relevant to this review.

* Corresponding author. Tel: +44351916685716,E-mail address: sergioncbarra@gmail.com

Published on behalf of the European Society of Cardiology. All rights reserved. (C) The Author 2014. For permissions please email: journals.permissions@oup.com. 


\section{Rates of cardioverter-defibrillator implantation in the elderly: are older patients well represented in randomized trials and registries?}

The average age of patients in the clinical trials of ICDs has been in $60 \mathrm{~s}$, ranging from $50 \mathrm{~s}$ to $70 \mathrm{~s}{ }^{1,2}$ Average age of patients at the time of study enrolment was between 58-65 years in secondary prevention trials ${ }^{3-5}$ and $58-66$ years in the primary prevention trials. ${ }^{1,2,6,7}$ Less than $25 \%$ of subjects included in the major clinical ICD trials are estimated to be $>75$. While most studies included a very low percentage of octogenarians, others have purposely excluded patients above the age of $80^{1,20,21}$ As such, prospective randomized trials are not representative of daily clinical practice. For this reason, it is not clear whether the survival benefit conferred by the ICD also extends to older patients with more limited life span (Table 1).

Data from national or international registries provide a reasonable estimate of the proportion of ICDs implanted in elderly patients in real-world clinical practice. Forty-two per cent of the 339.076 ICD implantations included in the United States National ICD registry over a 3-year period were $>70$ years old, while $12.4 \%$ were older than $>80 .{ }^{22}$ Of the 4.566 patients included in the Advancements in ICD Therapy Registry after first ICD or CRT-D implantation, 29\% per cent were 70-79 years old, while $12 \%$ were $>80 .^{8}$ The Ontario ICD Database included 5399 patients of which $31.6 \%$ were aged $70-79$ and $8.0 \%$ were $\geq 80$ years of age. ${ }^{23}$ Data of patients enrolled in the Italian ICD Registry for the years 2005-07 revealed that the median age of those treated with new implantation or replacement of ICD was 69 years, with ages 60 and 75 representing quartiles I and III, respectively. ${ }^{24}$ From November 1991 to May 2012, 5.3\% of 1428 patients admitted for ICD implantation or generator replacement in our Department were octogenarians. ${ }^{25}$

\section{Applicability: sudden cardiac death and ventricular arrhythmias in the elderly}

An analysis of 6252 patients with structural heart disease has shown that, although both sudden death and non-sudden death rates increase with age, the increase of non-sudden death is much more dramatic and the resultant SCD/all-cause mortality ratio diminishes progressively with advancing age (from 0.51 before age 50 to 0.26 after age 80). Importantly, age was the only clear-cut predictor of this change in risk in this patient population. ${ }^{26}$ An analysis of the pooled results of all secondary prevention ICD trials (AVID, CIDS, and $\mathrm{CASH}$ ), including a total of 1866 patients, of whom 252 were $\geq 75$ years old, has shown that over a mean follow-up of $2.3 \pm 1.9$ years the incidence of death from heart failure or non-cardiac causes was significantly higher among patients $\geq 75$ years old. ${ }^{18}$ However, the rate of arrhythmic death was similar between the two groups, resulting in a much lower relative contribution of SCD to all-cause mortality in the elderly group. Almost $20 \%$ of elderly patients ( $\geq 75$ years old) died within 1 year of their episode of lifethreatening ventricular arrhythmias, and at least three-quarters of these deaths were not potentially preventable by an ICD. ${ }^{18} \mathrm{Grimm}$ et al. ${ }^{27}$ followed 500 consecutive ICD patients and concluded that 5 -year overall mortality rate was much higher in patients $\geq 75$ vs. $<75$ years of age (55 vs. $21 \%$ ), mostly due to a higher mortality from heart failure.

However, Yung et al. ${ }^{23}$ observed that, although elderly patients show higher mortality rates after ICD implantation, rates of appropriate shocks are similar across age groups. In this prospective registry of 5399 ICD recipients, rates of appropriate shocks for primary and secondary prevention patients $>80$ years old were 4.2 events and 11.9 events per 100 person-years, respectively, similar to rates seen in younger patients. Appropriate ICD therapy was successful in terminating the arrhythmia in practically all cases and almost all elderly patients survived $>30$ days after the shock. The authors concluded

Table I Studies evaluating rates of ICD implantation in the elderly

\begin{tabular}{|c|c|c|}
\hline Study & Study Design & $\begin{array}{l}\text { Percentage of elderly } \\
\text { patients }\end{array}$ \\
\hline $\begin{array}{l}\text { United States National ICD } \\
\text { Registry }\end{array}$ & $\begin{array}{l}\text { - National registry } 2006-08 \\
\text { - } 339076 \text { ICD patients }\end{array}$ & $\begin{array}{l}>70 \text { years old } / 42 \% \\
>80 \text { years old } / 12.4 \%\end{array}$ \\
\hline $\begin{array}{l}\text { Advancements in ICD } \\
\text { Therapy Registry }\end{array}$ & $\begin{array}{l}\text { - Prospective 2-year study of largely community-based practice and reporting data from } 264 \\
\text { centres in the USA between November } 2004 \text { and March } 2006 \\
\text { - } 4566 \text { ICD/CRT-D patients }\end{array}$ & $\begin{array}{l}70-79 \text { years old } / 29 \% \\
\geq 80 \text { years old } / 12 \%\end{array}$ \\
\hline Ontario ICD Database ${ }^{23}$ & $\begin{array}{l}\text { - Population-based prospective registry, February 2007-September } 2010 \\
\text { - } 5399 \text { ICD patients }\end{array}$ & $\begin{array}{l}70-79 \text { years old } / 31.6 \% \\
\geq 80 \text { years old } / 8.0 \%\end{array}$ \\
\hline Italian ICD Registry ${ }^{24}$ & $\begin{array}{l}\text { - Prospective ICD registry for the years 2005-07 } \\
\text { - Number of ICDs per million of inhabitants: } 180.6 \text { in the year 2005, } 192.5 \text { in the year 2006, and } \\
220.6 \text { in the year } 2007\end{array}$ & $\geq 75$ years old $/ 25 \%$ \\
\hline $\begin{array}{l}\text { Papworth Hospital ICD } \\
\text { Registry }\end{array}$ & $\begin{array}{l}\text { - Prospective ICD registry, November 1991-May } 2012 \\
\text { - } 1428 \text { patients admitted for ICD implantation or generator replacement }\end{array}$ & $5.3 \%$ octogenarians \\
\hline
\end{tabular}

ICD, Implantable cardioverter-defibrillator; CRT-D, Cardiac resynchronization therapy defibrillator. 
that they had a similar likelihood of receiving appropriate device therapy and therefore they could potentially benefit from the ICD as much as their younger counterparts. ${ }^{23}$ In a different study, a similar ventricular tachyarrhythmia burden and number of ICD treatment interventions were observed in 159 patients $<75$ years of age vs. 49 who were $\geq 75 .^{28}$ Importantly, a higher mortality rate was seen in the elderly subgroup, almost exclusively of a non-sudden cardiac basis. ${ }^{28}$

Thus, in terms of reversing potentially life-threatening arrhythmias, the rationale for ICD therapy is comparable in older and younger individuals. Elderly patients do not seem more susceptible to unsuccessful shocks or electromechanical dissociation after ICD shock. However, an evaluation of the potential benefit of the ICD should not be based on rates of appropriate ICD therapies. Unnecessary, albeit terminologically appropriate, ICD therapy for non-sustained $\mathrm{VT}$ is an expanding concern and underlines the need for appropriate ICD programming. In the SCD-HeFT trial, $21 \%$ of the patients had appropriate shocks for fast VT or VF, yet the absolute reduction in mortality was only $7.2 \%$ at 5 years, ${ }^{2}$ while in the DEFINITE trial patients in the ICD group experienced twice as many appropriate shocks than there were fatal events in the control group. ${ }^{29}$ The MADIT-RIT study suggested that inappropriate or unnecessary shocks may in fact potentially increase mortality. ${ }^{30}$

\section{Safety: do elderly patients carry a higher risk of peri- and post-procedural complications? Primum non nocere!}

Tsai et al. ${ }^{31}$ evaluated the influence of age on perioperative complications among 150.264 primary prevention ICD recipients. The occurrence of any adverse event or in-hospital death increased from $2.8 \%$ in the youngest age group ( $<65$ years of age) to $4.5 \%$ in the oldest age groups ( $\geq 80$ years). Multivariate analysis found an increased odds of any adverse event or death among 75-79-year olds $(1.14[95 \% \mathrm{Cl}$, 1.03-1.25], 80-to 84-year-olds $(1.22$ [95\% Cl, 1.10-1.36], and patients 85 years and older $(1.15$ [ $95 \% \mathrm{Cl}, 1.01-1.32]$, compared with patients under 65 years old. Once patients reached 80 years of age, the rate of any events, including mortality, reached a plateau ( $4.5 \%$ in $80-84$ year old patients and $4.5 \%$ in those $\geq 85$ years old). The majority of complications were minor for all age groups. Importantly, comorbid conditions such as renal failure, stage IV heart failure, atrial fibrillation or 3rd degree heart block were stronger predictors than age in determining complication risks. Biventricular ICD placement, female gender, physician non-certification and device implantation by non-electrophysiologists were also as important, or even more so, than age in predicting complications. ${ }^{31}$ Yung and associates did not show any increase in the frequency of device-related complications within 45 days of implantation across the different age groups (except that younger primary prevention patients had higher inappropriate shock rates). ${ }^{23}$ Different studies corroborated these findings, reporting similar rates of procedure-, lead- and pulse generator-related complications between different age groups (including infection, lead failure and lead dislodgement), and a higher risk of inappropriate shocks in younger patients. ${ }^{27,32-36}$ Two large studies and a meta-analysis including randomized controlled trial (RCTs) and observational studies have shown that age is not an independent risk factor for increased ICD-related, operative, in-hospital, or longterm complications (Table 2). ${ }^{12,34,35}$

When referring an elderly patient for ICD implantation, physicians need to assess their risk of procedural and post-procedural complications. ${ }^{31}$ Based on data from 268701 ICD implants, Haines et al. ${ }^{37}$ developed a simple risk score consisting of 10 readily available variables that can accurately identify patients at high and low risk of complications. The risk of any in-hospital complication increased with increasing scores.

Although complications in new implants are relatively low in general, they may be potentially increased at the time of generator replacement $\left(4.1-5.8 \%{ }^{38,39}\right)$. However, detailed data on the risks and predictors of complications in a nationwide cohort in Denmark suggested that ICD generator replacement is less likely to cause complications than the initial device implantation and, in contrast with previous reports, age $>80$ years was associated with a $20 \%$ reduction in complication risk, mostly due to a marked reduction in the frequency of lead-related re-interventions. ${ }^{40}$

\section{Clinical effectiveness: does the elderly implantable cardioverter-defibrillator recipient live longer?}

\section{Estimate of the overall survival in elderly patients receiving ICDs: interaction agel survival}

Heart failure patients express meaningful preferences about quality vs. length of life, with younger patients preferring increased survival whereas older patients often consider quality of life (QoL) of greater importance. ${ }^{41}$ Although a discussion of the potential benefit of the ICD in elderly patients should not be limited to a comparison of mortality rates with vs. without the ICD, all-cause mortality is usually the most robust and easily assessed endpoint.

Observational studies have previously assessed survival of elderly patients following ICD implantation, ${ }^{23,33,42,43}$ whereas the first assessment of survival in octogenarians following ICD generator replacement was much more recent. ${ }^{25}$ Koplan et al. ${ }^{42}$ reported a median survival of 4.2 years in 107 primary prevention ICD patients aged $\geq 80$ years vs. 7 years in 242 sexagenarian ICD recipients. Patients with severe LV dysfunction and concurrent renal dysfunction had a median survival of only 19 months. Pellegrini et al reported a median survival of 5.3 years among 120 subjects $>75$ years old (24\% of cohort) who had transvenous ICD implantation or revision. After controlling for potential confounders and comorbidities, age at ICD implantation remained strongly associated with subsequent total, cardiac, and non-cardiac mortality. Importantly, divergence in survival occurred early and continued to increase throughout the follow-up time. The authors concluded that age itself should be considered a comorbidity when deeming appropriateness of ICD implantation, as it exerts an effect on mortality independent of baseline co-morbidity data. ${ }^{43}$ Van Rees et al. ${ }^{33}$ followed 1395 primary prevention ICD recipients and reported that, despite comparable rates 
Table 2 Studies evaluating the safety of ICD implantation in the elderly

\begin{tabular}{|c|c|c|}
\hline Study & Study population & Main findings \\
\hline Tsai et al. ${ }^{31}$ & $\begin{array}{l}\text { - Primary prevention ICD recipients within the } \\
\text { US NCDR ICD Registry } \\
\text { - } 150.264 \text { patients }(61 \% \geq 65 \text { years; } \\
16.1 \% \geq 80 \text { years old) }\end{array}$ & $\begin{array}{l}\text { - Occurrence of any peri-procedural adverse event or in-hospital death increased } \\
\text { from } 2.8 \% \text { in the youngest age group ( }<65 \text { years) to } 4.5 \% \text { in the oldest age groups } \\
\text { ( } \geq 80 \text { years) } \\
\text { - Renal failure, stage IV heart failure, atrial fibrillation, third degree heart block, } \\
\text { biventricular ICD placement, female gender, physician non-certification and device } \\
\text { implantation by non-electrophysiologists were stronger predictors of } \\
\text { complications than age }\end{array}$ \\
\hline Yung et al. ${ }^{23}$ & $\begin{array}{l}\text { Registry of } 5399 \text { ICD recipients in Ontario, } \\
\text { Canada }\end{array}$ & $\begin{array}{l}\text { - Rates of complications within } 45 \text { days of implantation: } 18-49 \text { years old }-7.5 \% \text {; } \\
70-79 \text { years old }-7.6 \% ; \geq 80 \text { years old }-10.7 \%(P=n s)\end{array}$ \\
\hline Grimm et al. $^{27}$ & $\begin{array}{l}500 \text { consecutive patients included in the } \\
\text { Marburg Defibrillator database }\end{array}$ & $\begin{array}{l}\text { All procedure-related, lead-related, and pulse generator-related complications were } \\
\text { similar in both patient groups ( } 23 \text { vs. } 25 \%) \text { during follow-up of } 48 \pm 39 \text { months }\end{array}$ \\
\hline Duray et al. ${ }^{32}$ & $\begin{array}{l}375 \text { consecutive ICD recipients with structural } \\
\text { heart disease }\end{array}$ & $\begin{array}{l}\text { Device associated complications were comparable in both groups } \\
\qquad(<70 \text { vs. } \geq 70 \text { years old })\end{array}$ \\
\hline Van Rees et al. ${ }^{33}$ & $\begin{array}{l}1395 \text { patients treated with a primary preventon } \\
\text { ICD }\end{array}$ & $\begin{array}{l}\text { - Lower rate of inappropriate shocks in patients } \geq 75 \text { years old } \\
\text { - Similar rate of different complications such as infection, lead failure, and lead } \\
\text { dislodgment in elderly patients ( } \geq 75 \text { years old) vs. the other sub-groups }\end{array}$ \\
\hline Reynolds et al. ${ }^{34}$ & $\begin{array}{l}\text { 31.000 Medicare beneficiaries receiving ICDs in } \\
2002-2003\end{array}$ & $\begin{array}{l}\text { Rate of one or more in-hospital complications related to ICD implantation was } 10.8 \% \\
\text { and age distribution was similar among patients who experienced complications } \\
\text { compared with those who did not }\end{array}$ \\
\hline Al-Khatib et al. ${ }^{35}$ & $\begin{array}{l}8581 \text { patients aged } \geq 65 \text { who received an ICD } \\
\text { between January } 2002 \text { and September } 2005\end{array}$ & Age was not an independent risk factor for increased complications \\
\hline $\begin{array}{l}\text { Noseworthy } \\
\text { et al. }^{36}\end{array}$ & $\begin{array}{l}183 \text { septuagenarian ICD recipients vs. } 29 \\
\text { octogenarians }\end{array}$ & $\begin{array}{c}\text { The complication rates at the time of ICD implantation were } 6.6 \% \text { in septuagenarians } \\
\text { and } 13.1 \% \text { in octogenarian, but difference was not statistically significant }\end{array}$ \\
\hline
\end{tabular}

ICD, Implantable cardioverter-defibrillator; CRT-D, cardiac resynchronization therapy defibrillator; US NCDR, United States National Cardiovascular Data Registry.

of appropriate shocks between different age groups, almost half of the patients $\geq 75$ vs. $15 \%$ of those $<65$ years old died in the first 5 years, and $22 \%$ vs. $5 \%$, respectively, died within 1 year following appropriate therapy. More recent data reported similar findings: 10.2 deaths per 100 person-years in primary prevention octogenarian patients and 15.5 deaths per 100 person-years in secondary prevention octogenarians. ${ }^{23}$ This study also suggested that death after appropriate shock is highest among elderly primary and secondary prevention patients (after an appropriate shock, the adjusted hazard ratios for death per decade were 1.28 and 1.34 for primary and secondary prevention, respectively). In our analysis of all ICD-related procedures carried out in octogenarian patients at our hospital between November 1991 and May 2012, we found the median additional years of life after ICD implantation in patients who died before data retrieval was 2.5 , and $65 \%$ of deceased patients after ICD implantation died in the first 3 years after the procedure. ${ }^{25}$ A different study concluded that mortality of patients $\geq 75$ years old was similar to that of the age-matched general population irrespective of delivery of ICD therapy. ${ }^{44}$ Conversely, Duray et al. ${ }^{32}$ concluded that elderly ICD recipients had comparable survival rates and appropriate use of the ICD compared with younger individuals.

The median survival of elderly ICD recipients should be taken into account. Taken as a whole, the overall life expectancy of octogenarians in the USA is 8 years, which is two-fold greater than that observed in octogenarian ICD recipients in the study by Koplan et al. ${ }^{42}$ Prior data reported 1 - and 5 -year survival of 80 and $40 \%$, respectively, in octogenarians following pacemaker implantation, ${ }^{45}$ and a 1-year mortality of 11.1 and $8.1 \%$ for elderly patients (age 75-91) with chronic coronary artery disease treated invasively or conservatively, respectively. ${ }^{46}$

\section{Subgroup analyses of the main implantable cardioverter-defibrillator trials and/or meta-analyses}

\section{Evidence in favour of implantable cardioverter-defibrillator implantation in the elderly}

A sub-group analysis of the MADIT-II trial revealed a 0.56 hazard ratio (95 Cl 0.29-1.08, $P=0.08$ ) for the mortality risk in patients $\geq 75$ years assigned to defibrillator implant compared with those in conventional therapy after a mean follow-up of 17.2 months (comparatively, the hazard ratio in patients $<75$ years assigned to defibrillator implant was 0.63 after 20.8 months, $\mathrm{Cl} 0.45-0.88, P=0.01) .{ }^{13}$ Few differences in sub-group characteristics were observed between patients $<75$ and $\geq 75$ years old, suggesting a highly careful selection of elderly patients qualifying for ICD treatment. It is noteworthy that, in the original MADIT-II trial, the survival curves between ICD and medical therapy-only subjects did not begin to diverge until 9 months after implant. ${ }^{1}$ In a prospective cohort study of 965 patients with ischaemic and non-ischaemic cardiomyopathies, severe LV dysfunction and no prior ventricular arrhythmias, a comparison was made between long-term mortality in patients who did vs. did not receive ICDs over a mean follow-up period of $34 \pm 16$ months. Although both the groups were similar in age and prevalence of most major comorbid conditions, ICD therapy was associated with a 31\% lower risk for allcause mortality, a mortality benefit similar to those seen in primary 
prevention trials and that persisted after stratification by age $(<65$, 65-74, and $\geq 75$ ). Implantable cardioverter-defibrillator therapy was associated with comparable absolute and relative mortality risk reductions in elderly patients despite higher annual mortality rates. ${ }^{14} \mathrm{Com}$ bining data from four RCTs (MUSTT, MADIT-II, DEFINITE, and SCD-HeFT), Kong et al. reported that primary prevention ICD therapy remains efficacious in reducing all-cause mortality in patients $\geq 75$ years of age, ${ }^{12}$ contradicting a similar meta-analysis published 1 year before. ${ }^{17} \mathrm{~A}$ recent paper by Earley and associates supports the benefit of the ICD in this age group. ${ }^{15}$

\section{Evidence against cardioverter-defibrillator implantation in the elderly}

The benefit of the ICD in primary prevention of SCD, according to MADIT II and SCD-HeFT, emerges only in a mid- to long-term follow-up (2-5 years). ${ }^{16}$ Given that the median survival of elderly patients with an ICD has been shown to be less than 5 years in most studies, ${ }^{25,33,42,43}$ the effectiveness of the ICD in prolonging their lives seems marginal. The SCD-HefT trial failed to demonstrate improved survival in patients $\geq 65$ years, and survival in the overall cohort was essentially the same for ICD and non-ICD patients alike for the first 18 months of follow-up. ${ }^{2}$ A meta-analysis by Santangeli et al had reported on pooled data of the DEFINITE, SCD-HeFT, and MADIT trials, but was unable to demonstrate significant survival benefit of the ICD in the elderly. ${ }^{17} \mathrm{~A}$ different metaanalysis pooled individual patient data from all three secondary prevention trials comparing ICD to amiodarone (AVID, CIDS and CASH) and concluded that ICD therapy did not seem to offer a survival benefit in secondary prevention patients $\geq 75$ years of age. $^{18}$ The AVID trial showed an unadjusted average of only 2.7 months of additional life gained at 3 years in a cohort of patients with mean age of $65 .^{19}$

\section{Selecting the patient for the procedure: which elderly patients to consider for an ICD?}

A previous study has shown that there is no significant difference in survival between clinical trial patients (MADIT-II and SCD-HeFT) randomized to receive an ICD and a similar group of clinical registry patients who received a primary prevention ICD, despite the fact the latter are significantly older and have more comorbidities. These results held even after limiting the analyses to patients 65 years and older. However, criticisms exist regarding the exclusion of many patients from analysis, stating that the clinical registry subgroup did not resemble a true cohort of patients in real-life practice. ${ }^{47}$

Although there are many elderly patients in whom implantation of an ICD is not appropriate because of comorbidities that may shorten life expectancy, Koplan et al. ${ }^{42}$ have shown that a proportion of elderly patients may survive for $\geq 4$ years after ICD implant. As the low-ejection fraction group has considerable risk heterogeneity, and multiple parameters may influence the risk of arrhythmic mortality among patients with similar degrees of left ventricular dysfunction, identification of those patients at high risk of early mortality who may not derive any benefit from ICD implantation is essential for optimal patient management. As 'reasonable expectation of survival' has not been standardized, physicians ultimately rely on their clinical judgement. How can life expectancy be determined in candidates for an ICD implantation? Although age is a predictor of mortality, it does not accurately identify patients who benefit vs. do not benefit from the ICD when used in isolation. Additional parameters must be taken into account. In this context, several risk stratification scores have been proposed to estimate the risk of potential ICD recipients $^{48-53}$ (Table 3). Their findings must be taken into context and mortality rates compared with those of the conventional therapy groups of the MADIT-II (19.8\% over a mean follow-up of 20 months) ${ }^{1}$ and SCD-HeFT trials (29\% over a mean follow-up of 45.5 months). ${ }^{2}$

(i) A MADIT-II sub-study stratified primary prevention patients based on the presence of five simple clinical parameters: age $>70$ years, heart failure functional class $>11$, blood urea nitrogen $>26 \mathrm{mg} / \mathrm{dL}$, QRS duration $>0.12 \mathrm{~s}$, and atrial fibrillation. ${ }^{48}$ While patients with no risk factors were shown to experience relatively low 2-year mortality rates without an ICD, thereby limiting a meaningful ICD effect within this time period, very high-risk patients (defined by urea levels $\geq 50 \mathrm{mg} / \mathrm{dL}$ and/or serum creatinine $\geq 2.5 \mathrm{mg} / \mathrm{dL}$ ) had 2-year mortality rates close to $50 \%$, with or without an ICD, and the predominant mode of death in this population was non-arrhythmic in nature. Implantable cardioverter-defibrillator therapy was associated with a $49 \%$ reduction in the risk of death among patients with one to two risk factors, while in patients with three risk factors or more mortality was only slightly lower in the ICD group than in the conventional therapy group ( $29 \mathrm{vs.}$ $32 \%){ }^{48}$ This risk score was subsequently validated in a longterm follow-up ${ }^{49}$ and a cohort of elderly patients. ${ }^{50}$

(ii) In their cohort of patients with an ICD, Chong et al..$^{52}$ have shown that those with clinical markers involving two or more organ systems had a 38\% 1-year mortality rate despite the ICD.

(iii) Based on $>45.000$ primary prevention ICD patients (of which $40 \%$ were $\geq 75$ years of age), Bilchick et al. developed a model ('SHOCKED') that accurately identified patients at highest risk of death after ICD implantation. ${ }^{53}$ In MADIT-II and SCD-HeFT, ${ }^{2}$ the $20 \%$ of patients with the highest predicted mortality rates after ICD implantation did not derive a survival benefit from ICD implantation. With this in mind, it was noteworthy that the $58 \%$ 3-year mortality rate for registry patients in the highest nomogram-based quintile of risk ${ }^{53}$ was even higher than the 3-year mortality rate for ICD patients in the highest risk quintile (42\%) from the SCD-HeFT analysis. ${ }^{2}$

(iv) The algorithm developed by Kraaier et al. comprised age $\geq 75$ years, LVEF $\leq 20 \%$, history of atrial fibrillation, and estimated glomerular filtration rate (GFR) $\leq 30 \mathrm{~mL} / \mathrm{min} / 1.73 \mathrm{~m}^{2}$ and was subsequently validated in a different cohort. Patients with three or more risk factors had 1-year mortality of 38.9 and $46.3 \%$ in the derivation and validation cohorts, respectively. ${ }^{54}$

(v) Data from MADIT-II have shown severe renal dysfunction to be the most powerful predictor of all-cause mortality during the course of the trial. While ICD therapy was associated with a survival benefit in each GFR category of $\geq 35 \mathrm{~mL} / \mathrm{min} /$ $1.73 \mathrm{~m}^{2}$, no benefit was shown among patients with a GFR of $<35 \mathrm{~mL} / \mathrm{min} / 1.73 \mathrm{~m}^{2} .^{55}$ Although patients with renal 
Table 3 Risk scores developed for the prediction of mortality in potential ICD recipients

\begin{tabular}{|c|c|c|}
\hline Study & Parameters included & Main findings \\
\hline $\begin{array}{l}\text { Goldenberg et al. }{ }^{48} \text { _MADIT-II sub-study, primary } \\
\text { prevention patients } \\
\text { Barsheshet et al. }{ }^{49} \text { —Validation in long-term follow-up } \\
\text { Anné et al. }{ }^{50} \text { - Validation in a cohort of elderly patients }\end{array}$ & $\begin{array}{l}\text { - Age }>70 \text { years } \\
\text { - NYHA class }>11 \\
\text { - Blood urea nitrogen } \\
>26 \mathrm{mg} / \mathrm{dL} \\
\text { - QRS duration }>0.12 \mathrm{~s} \\
\text { - Atrial fibrillation }\end{array}$ & $\begin{array}{l}\text { Crude mortality rates in the conventional group over a mean } \\
\text { period of } 20 \text { months were: } \\
\text { - ZERO risk factors }-9 \% \\
\text { - } \geq 1 \text { risk factors }-28 \% \\
\text { - Urea levels } \geq 50 \mathrm{mg} / \mathrm{dL} \text { and/or serum creatinine } \geq 2.5 \mathrm{mg} / \mathrm{dL} \\
-43 \% \\
\text { ICD therapy associated with a } 49 \% \text { reduction in the risk of death } \\
\text { among patients with } \geq 1 \text { risk factors, mostly among those } \\
\text { with } 1 \text { or } 2 \text { risk factors, whereas no benefit was seen in } \\
\text { patients with zero risk factors (HR } 0.96 \text { ) and in very-high risk } \\
\text { individuals (HR } 1.0 \text { ). Among patients with } \geq 3 \text { risk factors, } \\
\text { mortality was only slightly lower in the ICD group than in the } \\
\text { conventional therapy group ( } 29 \% \text { vs. } 32 \% \text { ). } \\
\text { While low-risk patients were shown to experience relatively } \\
\text { low } 2 \text {-year mortality rates without an ICD, very-high risk } \\
\text { patients had } 2 \text {-year mortality rates close to } 50 \% \text {, with or } \\
\text { without an ICD. }\end{array}$ \\
\hline $\begin{array}{l}\text { Parkash et al. } \\
469 \text { consecutive patients who underwent ICD } \\
\text { implantation at a single tertiary-care centre }\end{array}$ & $\begin{array}{l}\text { - Age }>80 \text { years } \\
\text { - History of atrial fibrillation } \\
\text { - Creatinine }>1.8 \mathrm{mg} / \mathrm{dL} \\
\text { - NYHA class III or IV }\end{array}$ & $\begin{array}{l}\text { One-year mortality significantly increased with increasing risk } \\
\text { score in both the prediction and validation cohorts. } \\
\text { Validation cohort mortality was: } \\
\text { - } 3.4 \% \text { for zero point } \\
\text { - } 4.3 \% \text { for one point } \\
\text { - } 17 \% \text { for two points } \\
\text { - } 33 \% \text { for three or more points } \\
\text { A risk score } \geq 2 \text { predicted a } 1 \text {-year mortality rate of } 21 \% \text {, } \\
\text { whereas a risk score of }<2 \text { predicted a mortality rate of } 4 \% \text { at } \\
1 \text { year. }\end{array}$ \\
\hline $\begin{array}{l}\text { Chong et al. } \\
283 \text { patients with de novo ICDs implanted for primary } \\
\text { or secondary prevention in ischaemic heart disease } \\
\text { and dilated cardiomyopathy }\end{array}$ & $\begin{array}{l}\text { - Liver dysfunction }{ }^{\mathrm{a}} \\
\text { - Respiratory dysfunction } \\
\text { - Renal dysfunction } \\
\text { - } \\
\text { - Anaemia } \\
\text { - Prior cerebral vascular } \\
\text { injury }\end{array}$ & $\begin{array}{l}\text { One-year mortality was: } \\
\text { - } 1.9 \% \text { with no organ dysfunction } \\
\text { - } 14.3 \% \text { with single organ dysfunction } \\
\text { - } 38.1 \% \text { with two or more markers of organ dysfunction }\end{array}$ \\
\hline $\begin{array}{l}\text { Bilchick et al. }^{53} \\
\text { Approximately } 45000 \text { Medicare beneficiaries } \\
\text { receiving primary prevention ICDs, 'SHOCKED' } \\
\text { model }\end{array}$ & $\begin{array}{l}\text { - } \geq 75 \text { years of age } \\
\text { - NYHA Class III } \\
\text { - Atrial fibrillation } \\
\text { - Chronic obstructive } \\
\text { pulmonary disease } \\
\text { - Chronic kidney disease } \\
\text { - LVEF } \leq 20 \% \\
\text { - Diabetes mellitus }\end{array}$ & $\begin{array}{l}\text { This model had C-statistics of } 0.75 \text { (95\% Cl } 0.75-0.76) \text { and } 0.74 \\
(95 \% \mathrm{Cl} 0.74-0.75) \text { in the development and validation } \\
\text { cohorts, respectively. Validation patients in the highest decile } \\
\text { of risk (nomogram score }>246 \text { ) had mortality rates after } 1,2 \text {, } \\
\text { and } 3 \text { years of } 28,44 \text {, and } 65 \% \text {, respectively. } \\
\text { Approximate } 1-, 2 \text {-, and } 3 \text {-year mortality rates (respectively) } \\
\text { according to the quintile of risk: } \\
\text { - First quintile: } 3,7,13 \% \\
\text { - Second quintile: } 4,11,21 \% \\
\text { - Third quintile: } 8,15,28 \% \\
\text { - Fourth quintile: } 13,25,40 \% \\
\text { - Fifth quintile: } 24,39,58 \%\end{array}$ \\
\hline $\begin{array}{l}\text { Kraaier et al. } \\
861 \text { prophylactic ICD recipients with ischaemic or } \\
\text { non-ischaemic DCM }\end{array}$ & $\begin{array}{l}\text { - } \text { Age } \geq 75 \text { years } \\
\text { - LVEF } \leq 20 \% \\
\text { - History of atrial fibrillation } \\
\text { - GFR } \leq 30 \mathrm{~mL} / \mathrm{min} / 1.73 \mathrm{~m}^{2}\end{array}$ & $\begin{array}{l}\text { A low ( } \leq 1 \text { factor), intermediate ( } 2 \text { factors), and high }(\geq 3 \\
\text { factors) risk group could be identified with } 1 \text {-year mortality } \\
\text { of, respectively, } 3.4,10.9 \text {, and } 38.9 \% \text {. } \\
\text { Afterwards, the risk score was validated in } 706 \text { primary } \\
\text { prevention patients: } 1 \text {-year mortality was } 2.5,13.2 \text {, and } \\
46.3 \% \text {, respectively }\end{array}$ \\
\hline
\end{tabular}

NYHA, New York Heart Association; LVEF, left ventricular ejection fraction.

${ }^{a} A S T$ or $A L T \geq 3 \times$ upper limit of normal or PT or INR $\geq 1.5$ in the absence of anticoagulation.

${ }^{b}$ Recent mechanical ventilation within 3 months prior to ICD implant.

${ }^{c}$ Creatinine $\geq 150 \mu \mathrm{mol} / \mathrm{L}$ or GFR $\leq 30 \mathrm{~mL} / \mathrm{min} / 1.73 \mathrm{~m}^{2}$.

dHaemoglobin $\leq 100 \mathrm{~g} / \mathrm{L}$.

dysfunction may be at higher risk of ICD therapies, ${ }^{56}$ there is enough evidence suggesting that patients with severe renal dysfunction do not get a survival benefit from the ICD. ${ }^{37,42,44,48,55}$ (vi) A more recent meta-analysis including 72 studies evaluating 63 mortality predictors in 257.692 ambulatory heart failure ICD recipients identified strong mortality predictors in these 
patients: ${ }^{57}$ age, baseline GFR, chronic obstructive pulmonary disease, diabetes, peripheral vascular disease, left ventricular ejection fraction, and appropriate or inappropriate ICD shocks.

(vii) Different studies have confirmed the negative survival impact of peripheral vascular disease, ${ }^{23,58}$ pulmonary disease, ${ }^{58}$ atrial fibrillation, ${ }^{59}$ and previous heart failure hospitalizations ${ }^{60}$ in ICD recipients. In regards to heart failure, a study by Eho et al suggested that women with this comorbidity have lower mortality than men, and fewer of those deaths are sudden throughout a spectrum of all-cause mortality risk. ${ }^{61}$

\section{Procedural aspects: what device and implantable cardioverter-defibrillator programming?}

The use of a single-chamber device and ICD programming to ventricular backup pacing at 40 b.p.m. should be strongly considered should there be no indication for pacing. ${ }^{62,63}$ However, the need to minimize right ventricular pacing is not age-specific. The PREPARE, ${ }^{64}$ MADIT-RIT, ${ }^{30}$ and ADVANCE-III ${ }^{65}$ studies and two very recent meta-analyses ${ }^{66,67}$ have clearly shown that programming high-rate and/or delayed therapy associates with reductions in unnecessary ICD therapy and may eventually decrease all-cause mortality. ${ }^{30}$ This may be relevant to the elderly population, as a subgroup analysis of the MADIT-RIT trial suggested that patients $>65$ years old had the largest survival benefit from high-rate ICD therapy. ${ }^{30}$

Also, a lower threshold for CRT implantation without defibrillator backup in the primary prevention elderly patient should perhaps be considered in light of recent evidence, suggesting that (i) CRT-D does not offer additional survival advantage over CRT-P at longer term follow-up, despite a trend at 1 year favouring the former; ${ }^{68}$ (ii) there is no survival benefit from CRT-D (vs. CRT-P) in patients deemed non-responders to $\mathrm{CRT}^{68}$ and (iii) the association between advanced age and adverse clinical outcomes (heart failure, death, and appropriate ICD therapy) is attenuated in elderly patients implanted with CRT-D devices compared with ICD only. ${ }^{69}$ When elderly patients with heart failure are at high risk of non-sudden mortality because of a high comorbidity burden, ${ }^{70}$ a CRT-P device rather than a CRT-D may be justified as symptomatic improvement and enhanced QoL are probably more relevant than reducing the risk of arrhythmic mortality. It should be noted that two previous studies have suggested that catheter ablation of ventricular tachycardia in elderly patients with structural heart disease is a relatively safe and effective procedure. ${ }^{71,72}$ It is reasonable to consider VT ablation as an alternative to the ICD in elderly patients who refuse ICD implantation or whose life expectancy is limited.

Figure 1 highlights the frequent dilemmas involved in the decision to give elderly patients an ICD, while Figure 2 lists the main similarities and differences between elderly patients and other age groups.

\section{Implantable cardioverter- defibrillator generator replacement at the end of battery life: is there any evidence of benefit in the very elderly?}

There are no current formal recommendations to guide physicians when elderly patients with ICDs require elective unit replacement (EUR).
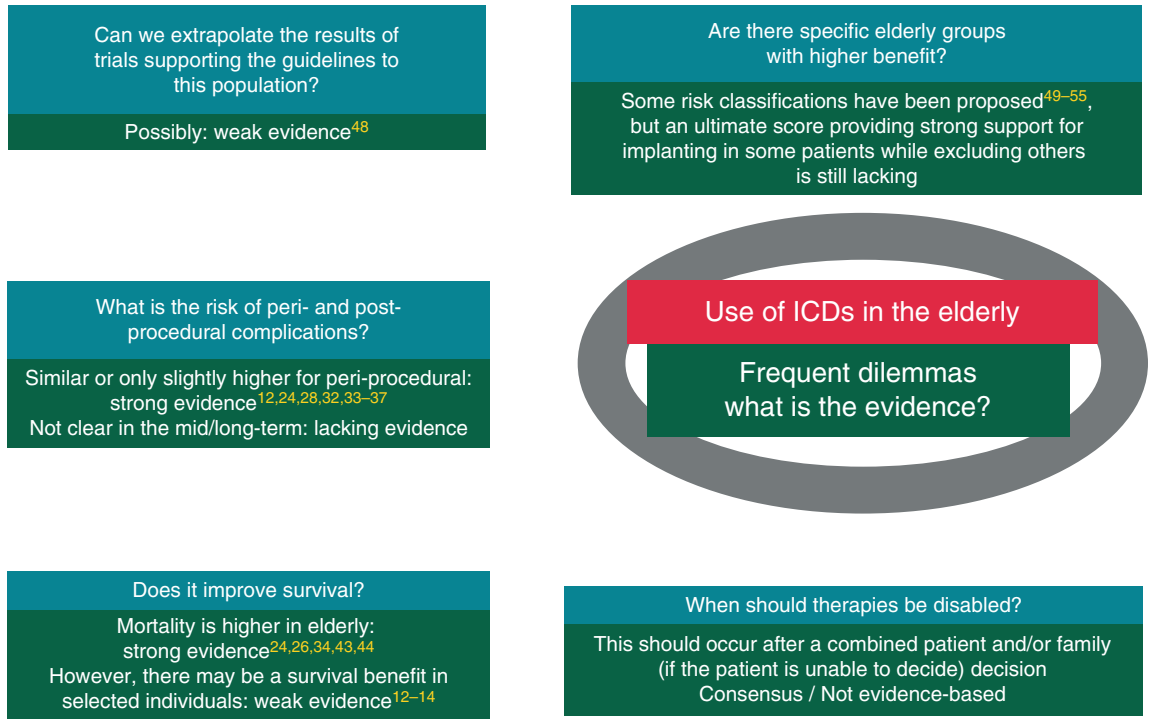

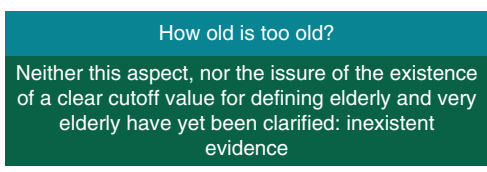

Is it cost-effective? For all patients?

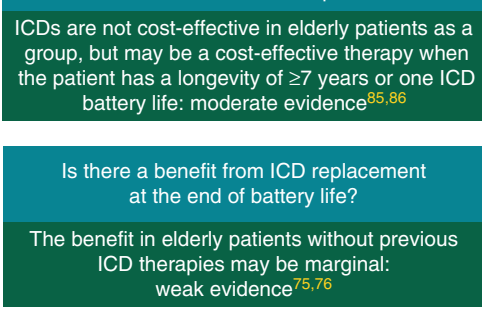

Is there a benefit from specific devices and/or programming?

Therapy reduction programming results in significant and consistent reduction in all-cause mortality in the overall ICD population, but this question has not been specifically addressed in the elderly: weak evidence

Figure I Frequent dilemmas involved in the use of ICDs in the elderly. ICD, implantable cardioverter-defibrillator. 
Use of ICDs in the elderly

Points to consider

in decision-making

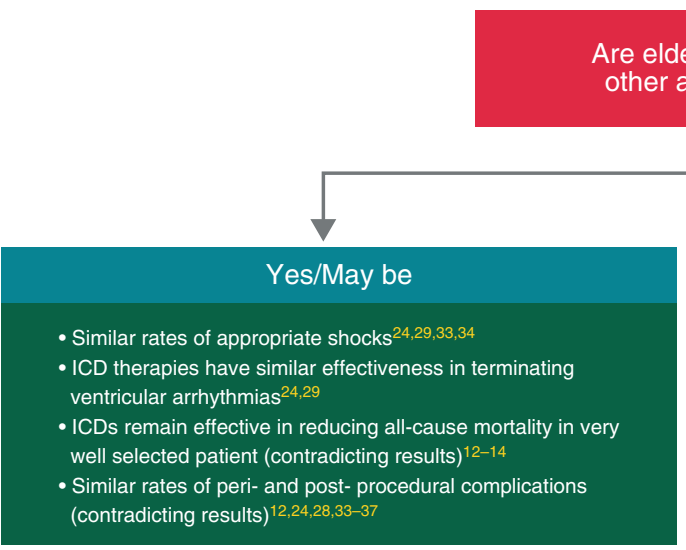

re elderly similar to

other age groups? 
ICD generator replacement in the elderly

Points to consider

in decision-making

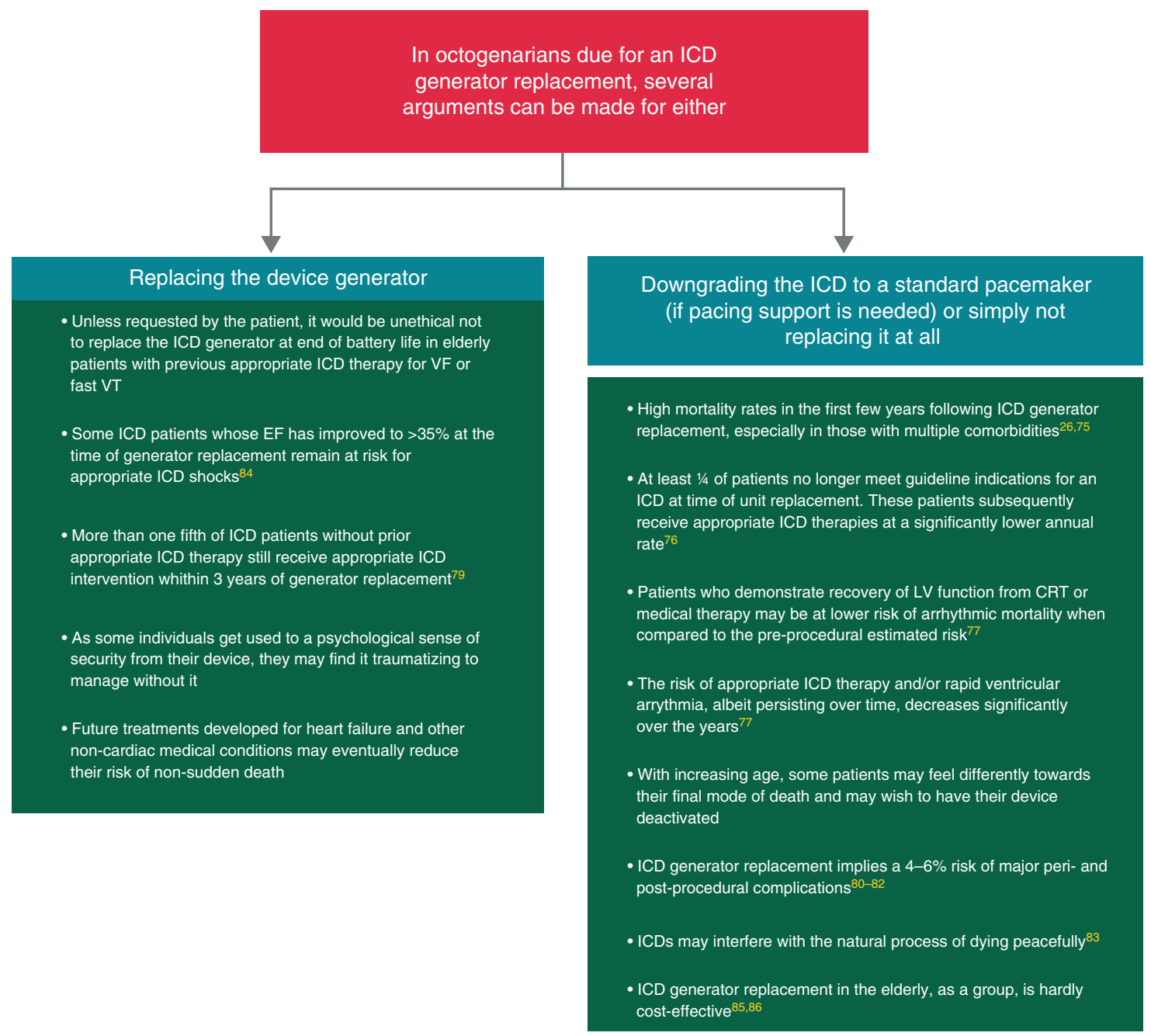

Figure 3 Implantable cardioverter-defibrillator generator replacement in the elderly: points to consider in decision-making. ICD, implantable cardioverter-defibrillator; VF, ventricular fibrillation; VT, ventricular tachycardia; LV, left ventricular; CRT, cardiac resynchronization therapy.

\section{Downgrading the implantable cardioverter-defibrillator to a standard pacemaker (if pacing support needed), explanting the device or simply not replacing it at all}

Mortality is high in the first few years following ICD generator replacement. $^{25,73}$ Patients who demonstrate recovery of LV function from CRT or medical therapy may be at lower risk of arrhythmic mortality when compared with the pre-procedural estimated risk ${ }^{76}$ and the absence of complex ventricular arrhythmias or appropriate ICD therapies since initial ICD implantation may be a surrogate for lower arrhythmic risk. Although the INSURE trial ${ }^{77}$ reported that
$21.4 \%$ of ICD patients without prior appropriate ICD therapy still received appropriate ICD intervention within 3 years of generator replacement, the vast majority of devices had been initially implanted for secondary prevention in the 1990s, well before the publication of studies showing that programming high-rate and/or delayed therapy associates with reductions in unnecessary ICD therapy. ${ }^{30,64,65} \mathrm{We}$ should also remember that ICD generator replacement implies a $4-6 \%$ risk of major peri- and post-procedural complications, ${ }^{78-80}$ although it is not clear whether elderly patients are at higher risk of complications. A recent study has shown that more than one-third of 125 deceased patients had ventricular tachyarrhythmia events with shocks within the last hour of life, with half of them receiving three or more shocks. Sixty-five per cent of patients with a do-not- 
resuscitate order still had shock therapy programmed 'on' at $24 \mathrm{~h}$ before death, which allowed for the delivery of shock treatment in almost one-fourth of them (Figure 3). ${ }^{81}$

\section{Replacing the device generator}

It would be unethical not to replace the ICD generator at end of battery life in elderly patients with previous appropriate ICD therapy for VF or fast VT, unless requested by the patient. Some ICD patients whose EF has improved to $>35 \%$ at the time of ICD generator replacement remain at risk for appropriate ICD shocks ${ }^{82}$ and up to $21.4 \%$ of ICD patients without prior appropriate ICD therapy may still receive appropriate ICD intervention within 3 years of generator replacement (Figure 3). ${ }^{77}$

\section{Cost-effectiveness: is it cost-effective to give elderly patients an implantable cardioverter-defibrillator?}

With the expansion of the population eligible for an ICD, resource limitations and discussions of cost-effectiveness have come to the forefront. The cost-effectiveness of the ICD in routine clinical practice seems less obvious in certain sub-groups of patients, particularly in the case of elderly patients who are at higher risk of non-arrhythmic death.

As most costs associated with ICD implantation occur in the early phase of treatment, cost-effectiveness may become more favourable as patients live longer, the battery life of ICDs extends, cost of the device is reduced and improvements to efficacy occur (improved patient selection, minimized unnecessary shock). Patient longevity increases the cost-effectiveness of the ICD. In the MADIT-II trial, ${ }^{1}$ the number needed to treat to prevent one additional primary outcome decreased from 17 at the end of the first 2 years to 8 when follow-up was extended to 8 years.

On the basis of data from eight large primary prevention trials, the incremental cost-effectiveness of prophylactic ICD therapy has been estimated to range from $\$ 34.000$ to $\$ 70.200$ per quality-adjusted life year (QALY) added. ${ }^{83}$ The authors claimed that costs would remain $<\$ 100000$ per QALY as long as mortality was reduced for $\geq 7$ years, with estimated costs escalating quickly as the duration of efficacy was reduced. If the survival time horizon was reduced to 5 years after ICD implantation, as in patients $\geq 75$ years described by Pelligrini et al., ${ }^{43}$ cost estimates would vary between $\$ 90.000$ and $\$ 250.000$. Though a single threshold for cost-effectiveness has not been properly established, values ranging from $\$ 50.000$ to $\$ 120.000$ per QALY have been proposed. ${ }^{84}$ In this context, it is highly relevant that the average median survival of elderly ICD recipients ( $\geq 75$ years old) does not seem to surpass the 5 -year mark in most studies, ${ }^{25,33,42,43}$ with much shorter lifespan in patients with multiple comorbidities. In fact, current data do not support the assumption that ICD therapy has a persistent effect on late survival. A meta-analysis of secondary prevention trials showed a convergence of survival curves for ICD and control arms at 4 years and a life extension of just 4.4 months over a follow-up period of 6 years, ${ }^{85}$ while patients receiving appropriate shocks in the SCD-HeFT and MADIT-II studies had a poor short-term prognosis. ${ }^{86,87}$ In the latter, based on an average survival gain of only 2 months and a three-fold higher rate of hospitalizations, the incremental cost-effectiveness ratio was $\$ 235.000$ per year of life saved, unadjusted for QoL. ${ }^{88}$ A similar finding was reported from the CIDS trial in secondary prevention. ${ }^{89}$ Thus, ICD intervention among the elderly, as a group, may not be cost-effective. To reach costeffectiveness in the elderly, limiting their application to those expected to live $>5$ years after implantation, or rather one ICD battery-life, would be necessary.

An important aspect of cost-effectiveness is the assessment of the impact on QoL. In the case of ICD therapy, evidence remains conflicting and relatively weak. The only study examining the relationship between age and QoL in the setting of a RCT was a MADIT-II substudy that found no significant differences in QALY between control and ICD groups and between patients younger and older than $65 .{ }^{90}$ The largest QoL study in ICD recipients for primary prevention of SCD was performed in the SCD-HeFT population, yet the effect of age on QoL was not examined. In fact, there is little QoL data on the use of ICDs in elderly patients, which is a paradox as QoL is often a critical factor in clinical decision-making in the elderly. However, while older patients with ICDs have decreased physical functioning, more co-morbid illness, and worse symptoms that negatively impact QoL, younger patients with ICDs tend to experience increased psychological distress, anxiety, and depression. ${ }^{91,92}$ Implantable cardioverter-defibrillator impact on QoL goes much beyond the deleteriously impact of recurrent or unnecessary shocks. Reynolds et al. ${ }^{34}$ found one or more complications in $11 \%$ of the procedures which were associated with highly significant increase in the length of hospital stay (1-10 days) and hospital costs $(\$ 5.000-$ $\$ 20.000$ ). Also, recent data suggest that device-related infection increased by $1 \%$ in the last decade, reaching $2.41 \%$ of all implants in $2008 .^{93}$ The hospitalization of elderly patients tends to be more prolonged and susceptible to clinical intercurrences and thus more costly.

\section{Conclusions}

Implantable cardioverter-defibrillator implantation may reduce mortality in the elderly, but it should be recognized to constitute a smaller absolute clinical benefit. Termination of ventricular arrhythmias by ICD therapies could prevent sudden death, but probably results in a marginal prolongation of life, due to high competing risk for nonSCD. Alongside with the expensive cost, the possibility of adversely affecting QoL and increasing comorbidity burden may lead to difficulties in justifying this therapy in the elderly population. Nevertheless, in those very well-selected elderly patients at high risk of arrhythmic death and with minimum comorbidities despite advanced age, ICD intervention may reduce mortality to near age-specific life-expectancy. Therefore, biological age (possibly assessed through a multivariable score, which is yet to be optimized) rather than chronological age per se should be the decisive factor in making a decision on ICD selection for survival benefit.

Conflict of interest: none declared.

\section{References}

1. Moss AJ, Zareba W, HallWJ, Klein H, Wilber DJ, Cannom DS et al. Multicenter Automatic Defibrillator Implantation Trial II Investigators. Prophylactic implantation of a 
defibrillator in patients with myocardial infarction and reduced ejection fraction. $N$ Engl J Med 2002;346:877-83.

2. Bardy GH, Lee KL, Mark DB, Poole JE, Packer DL, Boineau R et al. Sudden Cardiac Death in Heart Failure Trial (SCD-HeFT) Investigators. Amiodarone or an implantable cardioverter-defibrillator for congestive heart failure. N Engl J Med 2005; 352:225-37.

3. The Antiarrhythmics Versus Implantable Defibrillators (AVID) Investigators. A comparison of antiarrhythmic drug therapy with implantable defibrillators in patients resuscitated from near-fatal ventricular arrhythmias. N Engl J Med 1997;337: 1576-83.

4. Connolly SJ, Gent M, Roberts RS, Dorian P, Roy D, Sheldon RS et al. Canadian implantable defibrillator study (CIDS): a randomized trial of the implantable cardioverter defibrillator against amiodarone. Circulation 2000;101:1297-302.

5. Kuck KH, Cappato R, Siebels J, Rüppel R. Randomized comparison of antiarrhythmic drug therapy with implantable defibrillators in patients resuscitated from cardiac arrest: the Cardiac Arrest Study Hamburg (CASH). Circulation 2000;102:748-54.

6. Moss AJ, Hall WJ, Cannom DS, Daubert JP, Higgins SL, Klein H et al. Improved survival with an implanted defibrillator in patients with coronary disease at high risk for ventricular arrhythmia. Multicenter automatic defibrillator implantation trial investigators. N Engl J Med 1996;335:1933-40.

7. Buxton AE, Lee KL, Fisher JD, Josephson ME, Prystowsky EN, Hafley G. A randomized study of the prevention of sudden death in patients with coronary artery disease. Multicenter unsustained tachycardia trial investigators. N Engl J Med 1999; 341:1882-90.

8. Epstein AE, Kay GN, Plumb VJ, McElderry HT, Doppalapudi H, Yamada T et al. Implantable cardioverter-defibrillator prescription in the elderly. Heart Rhythm 2009;6:1136-43.

9. Ruskin JN, Camm AJ, Zipes DP, Hallstrom AP, McGrory-Usset ME. Implantable cardioverter defibrillator utilization based on discharge diagnoses from Medicare and managed care patients. J Cardiovasc Electrophysiol 2002;13:38-43.

10. Wiener JM, TillyJ. Population ageing in the United States of America: implications for public programmes. Int J Epidemiol 2002;31:776-81.

11. Anderson GF, Hussey PS. Population aging: a comparison among industrialized countries. Health Aff (Millwood) 2000;19:191-203.

12. Kong MH, Al-Khatib SM, Sanders GD, Hasselblad V, Peterson ED. Use of implantable cardioverter-defibrillators for primary prevention in older patients: a systematic literature review and meta-analysis. Cardiol / 2011;18:503-14.

13. Huang DT, Sesselberg HW, McNitt S, Noyes K, Andrews ML, Hall WJ et al. MADIT-II Research Group. Improved survival associated with prophylactic implantable defibrillators in elderly patients with prior myocardial infarction and depressed ventricular function: a MADIT-II substudy. J Cardiovasc Electrophysiol 2007;18:833-8.

14. Chan PS, Nallamothu BK, Spertus JA, Masoudi FA, Bartone C, Kereiakes DJ et al. Impact of age and medical comorbidity on the effectiveness of implantable cardioverter-defibrillators for primary prevention. Circ Cardiovasc Qual Outcomes 2009;2:16-24.

15. Earley A, Persson R, Garlitski AC, Balk EM, Uhlig K. Effectiveness of implantable cardioverter defibrillators for primary prevention of sudden cardiac death in subgroups a systematic review. Ann Intern Med 2014;160:111-21.

16. Boriani G, Ricci R, Toselli T, Ferrari R, Branzi A, Santini M. Implantable cardioverter defibrillators: from evidence of trials to clinical practice. Eur Heart J Suppl 2007;9: 166-73.

17. Santangeli P, Di Biase L, Dello RA, Casella M, Bartoletti S, Santarelli $P$ et al. Meta-analysis: age and effectiveness of prophylactic implantable cardioverter defibrillators. Ann Intern Med 2010;153:592-9.

18. Healey JS, Hallstrom AP, Kuck KH, Nair G, Schron EP, Roberts RS et al. Role of the implantable defibrillator among elderly patients with a history of life threatening ventricular arrhythmias. Eur Heart J 2007;28:1746-9.

19. Russo AM, Stainback RF, Bailey SR, Epstein AE, Heidenreich PA, Jessup Met al. ACCF/ HRS/AHA/ASE/HFSA/SCAI/SCCT/SCMR 2013 appropriate use criteria for implantable cardioverter-defibrillators and cardiac resynchronization therapy: a report of the American College of Cardiology Foundation appropriate use criteria task force, Heart Rhythm Society, American Heart Association, American Society of Echocardiography, Heart Failure Society of America, Society for Cardiovascular Angiography and Interventions, Society of Cardiovascular Computed Tomography, and Society for Cardiovascular Magnetic Resonance. J Am Coll Cardiol 2013;61:1318-68.

20. Hohnloser SH, Kuck KH, Dorian P, Roberts RS, HamptonJR, Hatala Retal. DINAMIT Investigators. Prophylactic use of an implantable cardioverter-defibrillator after acute myocardial infarction. N Eng J Med 2004;351:2481-8.

21. Bigger JTJr. Prophylactic use of implanted cardiac defibrillators in patients at high risk for ventricular arrhythmia after coronary-artery bypass graft surgery. Coronary Artery Bypass Graft (CABG) Patch Trial Investigations. N Engl J Med 1966;335: 1933-40.

22. Hammill SC, Kremers MS, Kadish AH, Stevenson LW, Heidenreich PA, Lindsay BD et al. Review of the ICD registry's third year, expansion to include lead data and pediatric ICD procedures, and role for measuring performance. Heart Rhythm 2009;6:1397-401.

23. Yung D, Birnie D, Dorian P, Healey JS, Simpson CS, Crystal E et al. Survival after implantable cardioverter-defibrillator implantation in the elderly. Circulation 2013; 127:2383-92.

24. Proclemer A, Ghidina M, Gregori D, Facchin D, Rebellato L, Fioretti P et al. Impact of the main implantable cardioverter-defibrillator trials in clinical practice: data from the Italian ICD Registry for the years 2005-07. Europace 2009;11:465-75.

25. Goonewardene M, Barra S, Heck P, Begley D, Fynn S, Virdee M et al. Cardioverterdefibrillator implantation and generator replacement in the octogenarian. Europace, doi:10.1093/europace/euu248.

26. Krahn AD, Connolly SJ, Roberts RS, Gent M. ATMA Investigators. Diminishing proportional risk of sudden death with advancing age: implications for prevention of sudden death. Am Heart J 2004;147:837-40.

27. Grimm W, Stula A, Sharkova J, Alter P, Maisch B. Outcomes of elderly recipients of implantable cardioverter defibrillators. Pacing Clin Electrophysiol 2007;30:S134-8.

28. Ermis C, Zhu AX, Vanheel L, Sakaguchi RN, Lurie KG, Lu F et al. Comparison of ventricular arrhythmia burden, therapeutic interventions, and survival, in patients $<75$ and patients $>$ or $=75$ years of age treated with implantable cardioverter defibrillators. Europace 2007;9:270-4.

29. Kadish A, Dyer A, Daubert JP, Quigg R, Estes NA, Anderson KP et al. Defibrillators in Non-Ischemic Cardiomyopathy Treatment Evaluation (DEFINITE) Investigators. Prophylactic defibrillator implantation in patients with nonischemic dilated cardiomyopathy. N Engl J Med 2004;350:2151-8.

30. Moss AJ, Schuger C, Beck CA, Brown MW, Cannom DS, DaubertJPet al. MADIT-RIT Trial Investigators. Reduction in inappropriate therapy and mortality through ICD programming. N Engl J Med 2012;367:2275-83.

31. Tsai $\bigvee$, Goldstein MK, Hsia HH, Wang Y, Curtis J, Heidenreich PA. National Cardiovascular Data's ICD Registry. Influence of age on perioperative complications among patients undergoing implantable cardioverter-defibrillators for primary prevention in the United States. Circ Cardiovasc Qual Outcomes 2011;4:549-56.

32. Duray G, Richter S, Manegold J, Israel CW, Grönefeld G, Hohnloser SH. Efficacy and safety of ICD therapy in a population of elderly patients treated with optimal background medication. J Interv Card Electrophysiol 2005;14:169-73.

33. van Rees JB, Borleffs CJ, Thijssen J, de Bie MK, van Erven L, Cannegieter SC et al. Prophylactic implantable cardioverter-defibrillator treatment in the elderly: therapy, adverse events, and survival gain. Europace 2012;14:66-73.

34. Reynolds MR, Cohen DJ, Kugelmass AD, Brown PP, Becker ER, Culler SD et al. The frequency and incremental cost of major complications among medicare beneficiaries receiving implantable cardioverter-defibrillators. J Am Coll Cardiol 2006;47: 2493-7.

35. Al-Khatib SM, Greiner MA, Peterson ED, Hernandez AF, Schulman KA, Curtis LH. Patient and implanting physician factors associated with mortality and complications after implantable cardioverter-defibrillator implantation, 2002-2005. Circ Arrhythmia Electrophysiol 2008;1:240-9.

36. Noseworthy PA, Lashevsky I, Dorian P, Greene M, Cvitkovic S, Newman D. Feasibility of implantable cardioverter defibrillator use in elderly patients: a case series of octogenarians. Pacing Clin Electrophysiol 2004;27:373-8.

37. Haines DE, Wang Y, Curtis J. Implantable cardioverter-defibrillator registry risk score models for acute procedural complications or death after implantable cardioverter-defibrillator implantation. Circulation 2011;123:2069-76.

38. Costea A, Rardon DP, Padanilam BJ, Fogel RI, Prystowsky EN. Complications associated with generator replacement in response to device advisories. J Cardiovasc Electrophysiol 2008;19:266-9.

39. Gould PA, Krahn AD. Complications associated with implantable cardioverterdefibrillator replacement in response to device advisories. JAMA 2006;295: 1907-11.

40. Kirkfeldt RE, Johansen JB, Nohr EA, Jørgensen OD, Nielsen JC. Complications after cardiac implantable electronic device implantations: an analysis of a complete, nationwide cohort in Denmark. Eur Heart J 2014;35:1186-94.

41. Lewis EF, Johnson PA, Johnson W, Collins C, Griffin L, Stevenson LW. Preferences for quality of life or survival expressed by patients with heart failure. J Heart Lung Transplant 2001;20:1016-24.

42. Koplan BA, Epstein LM, Albert CM, Stevenson WG. Survival in octogenarians receiving implantable defibrillators. Am Heart J 2006;152:714-9.

43. Pellegrini CN, Lee K, Olgin JE, Turakhia MP, Tseng ZH, Lee R et al. Impact of advanced age on survival in patients with implantable cardioverter defibrillators. Europace 2008;10:1296-301.

44. Brüllmann S, Dichtl W, Paoli U, Haegeli L, Schmied C, Steffel J et al. Comparison of benefit and mortality of implantable cardioverter-defibrillator therapy in patients aged $\geq 75$ years versus those $<75$ years. Am J Cardiol 2012;109:712-7.

45. Shen WK, Hayes DL, Hammill SC, Bailey KR, Ballard DJ, Gersh BJ. Survival and functional independence after implantation of a permanent pacemaker in octogenarians and nonagenarians. A population-based study. Ann Intern Med 1996;125:476-80. 
46. Pfisterer M, Buser P, Osswald S, Allemann U, Amann W, Angehrn W et al. Outcome of elderly patients with chronic symptomatic coronary artery disease with an invasive vs optimized medical treatment strategy: one-year results of the randomized TIME trial. JAMA 2003;289:1117-23.

47. Al-Khatib SM, Hellkamp A, Bardy GH, Hammill S, Hall WJ, Mark DB et al. Survival of patients receiving a primary prevention implantable cardioverter-defibrillator in clinical practice vs clinical trials. JAMA 2013;309:55-62.

48. Goldenberg I, Vyas AK, HallWJ, Moss AJ, Wang H, He Hetal. MADIT-II Investigators. Risk stratification for primary implantation of a cardioverter-defibrillator in patients with ischemic left ventricular dysfunction. J Am Coll Cardiol 2008;51:288-96.

49. Barsheshet A, Moss AJ, Huang DT, McNitt S, Zareba W, Goldenberg I. Applicability of a risk score for prediction of the long-term (8-year) benefit of the implantable cardioverter-defibrillator. J Am Coll Cardiol 2012;59:2075-9.

50. Anné W, Theuns DA, Schaer B, Van Belle Y, Szili-Torok T, Smith T et al. ICDs at higher age and clinical risk factors. Neth Heart J 2014;22:279-85.

51. Parkash R, Stevenson WG, Epstein LM, Maisel WH. Predicting early mortality after implantable defibrillator implantation: a clinical risk score for optimal patient selection. Am Heart J 2006;151:397-403.

52. Chong D, Tan BY, Ho KL, Liew R, Teo WS, Ching CK. Clinical markers of organ dysfunction associated with increased 1-year mortality post-implantable cardioverter defibrillator implantation. Europace 2013;15:508-14.

53. Bilchick KC, Stukenborg G], Kamath S, Cheng A. Prediction of mortality in clinical practice for medicare patients undergoing defibrillator implantation for primary prevention of sudden cardiac death. J Am Coll Cardiol 2012;60:1647-55.

54. Kraaier K, Scholten MF, Tijssen JG, Theuns DA, Jordaens LJ, Wilde AA et al. Early mortality in prophylactic implantable cardioverter-defibrillator recipients: development and validation of a clinical risk score. Europace 2014;16:40-6.

55. Goldenberg I, Moss AJ, McNitt S, Zareba W, Andrews ML, Hall WJ et al. Multicenter Automatic Defibrillator Implantation Trial-II Investigatorset al. Relations among renal function, risk of sudden cardiac death, and benefit of the implanted cardiac defibrillator in patients with ischemic left ventricular dysfunction. Am J Cardiol 2006;98: 485-90.

56. Hreybe H, Ezzeddine R, Bedi M, Barrington W, Bazaz R, Ganz LI et al. Renal insufficiency predicts the time to first appropriate defibrillator shock. Am Heart J2006;151: 852-6.

57. Alba AC, Braga J, Gewarges M, Walter SD, Guyatt GH, Ross HJ. Predictors of mortality in patients with an implantable cardiac defibrillator: a systematic review and meta-analysis. Can J Cardiol 2013;29:1729-40.

58. Lee DS, Tu JV, Austin PC, Dorian P, Yee R, Chong A et al. Effect of cardiac and noncardiac conditions on survival after defibrillator implantation. J Am Coll Cardiol 2007; 49:2408-15.

59. Bunch TJ, Day JD, Olshansky B, Stolen KQ, Mullin CM. INTRINSIC RV Study Investigators. Newly detected atrial fibrillation in patients with an implantable cardioverterdefibrillator is a strong risk marker of increased mortality. Heart Rhythm 2009;6:2-8.

60. Chen CY, Stevenson LW, Stewart GC, Seeger JD, Williams L, Jalbert IJ et al. Impact of baseline heart failure burden on post-implantable cardioverter-defibrillator mortality among medicare beneficiaries. J Am Coll Cardiol 2013;61:2142-50.

61. Rho RW, Patton KK, Poole JE, Cleland JG, Shadman R, Anand I et al. Important differences in mode of death between men and women with heart failure who would qualify for a primary prevention implantable cardioverter-defibrillator. Circulation 2012;126:2402-7.

62. Peterson PN, Varosy PD, Heidenreich PA, Wang Y, Dewland TA, Curtis JP et al. Association of single- vs dual-chamber ICDs with mortality, readmissions, and complications among patients receiving an ICD for primary prevention. JAMA 2013;309: 2025-34.

63. Wilkoff BL, Cook JR, Epstein AE, Greene HL, Hallstrom AP, Hsia $\mathrm{H}$ et al. Dual Chamber and VVI Implantable Defibrillator Trial Investigators. Dual-chamber pacing or ventricular backup pacing in patients with an implantable defibrillator: the Dual Chamber and VVI Implantable Defibrillator (DAVID) trial. JAMA 2002;288: 3115-23.

64. Wilkoff BL, Williamson BD, Stern RS, Moore SL, Lu F, Lee SW et al. PREPARE Study Investigators. Strategic programming of detection and therapy parameters in implantable cardioverter-defibrillators reduces shocks in primary prevention patients: results from the PREPARE (Primary Prevention Parameters Evaluation) study. J Am Coll Cardiol 2008;52:541-50.

65. Gasparini M, Proclemer A, Klersy C, Kloppe A, Lunati M, Ferrer JB et al. Effect of longdetection interval vs standard-detection interval for implantable cardioverterdefibrillators on antitachycardia pacing and shock delivery: the ADVANCE III randomized clinical trial. JAMA 2013;309:1903-11.

66. Tan VH, Wilton SB, Kuriachan V, Sumner GL, Exner DV. Impact of programming strategies aimed at reducing nonessential implantable cardioverter defibrillator therapies on mortality: a systematic review and meta-analysis. Circ Arrhythm Electrophysiol 2014;7:164-70.
67. Scott PA, Silberbauer J, McDonagh TA, Murgatroyd FD. Impact of prolonged implantable cardioverter-defibrillator arrhythmia detection times on outcome: a meta-analysis. Heart Rhythm 2014;11:828-35.

68. Looi KL, Gajendragadkar PR, Khan FZ, Elsik M, Begley DA, Fynn SP et al. Cardiac resynchronisation therapy: pacemaker versus internal cardioverter-defibrillator in patients with impaired left ventricular function. Heart 2014; Apr 1. doi: 10.1136/ heartjnl-2014-305537. [Epub ahead of print]

69. Suleiman M, Goldenberg I, Haim M, Schliamser JE, Boulos M, Ilan M et al. Israeli Working Group on Pacing and Electrophysiology. Clinical characteristics and outcomes of elderly patients treated with an implantable cardioverter-defibrillator or cardiac resynchronization therapy in a real-world setting: data from the Israeli ICD registry. Heart Rhythm 2014;11:435-41.

70. Theuns DA, Schaer BA, Soliman OI, Altmann D, Sticherling C, Geleijnse ML et al. The prognosis of implantable defibrillator patients treated with cardiac resynchronization therapy: comorbidity burden as predictor of mortality. Europace 2011;13: $62-9$.

71. Viana-Tejedor A, Merino JL, Pérez-Silva A, León RC, Reviriego SM, Caraballo ED et al. Effectiveness of catheter ablation of ventricular tachycardia in elderly patients with structural heart disease. Rev EspCardiol 2010;63:156-60.

72. Inada K, Roberts-Thomson KC, Seiler J, Steven D, Tedrow UB, Koplan BA et al. Mortality and safety of catheter ablation for antiarrhythmic drug-refractory ventricular tachycardia in elderly patients with coronary artery disease. Heart Rhythm 2010;7: 740-4.

73. Kramer DB, Kennedy KF, Spertus JA, Normand SL, Noseworthy PA, Buxton AE et al. Mortality risk following replacement implantable cardioverter-defibrillator implantation at end of battery life: results from the NCDR®. Heart Rhythm 2014; 11:216-21.

74. Kini V, Soufi MK, Deo R, Epstein AE, Bala R, Riley M et al. Appropriateness of primary prevention implantable cardioverter defibrillators at time of generator replacement: are indications still met? J Am Coll Cardiol 2014;63:2388-94.

75. Alsheikh-Ali AA, Homer M, Maddukuri PV, Kalsmith B, Estes NA 3rd, Link MS. Time-dependence of appropriate implantable defibrillator therapy in patients with ischemic cardiomyopathy.J Cardiovasc Electrophysiol 2008;19:784-9.

76. Schliamser JE, Kadish AH, Subacius H, Shalaby A, Schaechter A, Levine J et al. DEFINITE Investigators. Significance of follow-up left ventricular ejection fraction measurements in the Defibrillators in Non-Ischemic Cardiomyopathy Treatment Evaluation trial (DEFINITE). Heart Rhythm 2013;10:838-46.

77. Erkapic D, Sperzel J, Stiller S, Meltendorf U, Mermi J, Wegscheider K et al. INSURE Investigators. Long-term benefit of implantable cardioverter/defibrillator therapy after elective device replacement: results of the INcidence free SUrvival after ICD REplacement (INSURE) trial—a prospective multicentre study. Eur Heart J 2013; 34:130-7.

78. Krahn AD, Lee DS, Birnie D, Healey JS, Crystal E, Dorian P et al. Ontario ICD Database Investigators. Predictors of short-term complications after implantable cardioverter-defibrillator replacement: results from the Ontario ICD Database. Circ Arrhythm Electrophysiol 2011;4:136-42.

79. Gould PA, Gula LJ, Champagne J, Healey JS, Cameron D, Simpson C et al. Outcome of advisory implantable cardioverter-defbrillator replacement: one-year follow-up. Heart Rhythm 2008;5:1675-81.

80. Poole JE, Gleva MJ, Mela T, Chung MK, Uslan DZ, Borge R et al. REPLACE Registry Investigators. Complication rates associated with pacemaker or implantable cardioverter-defibrillator generator replacements and upgrade procedures: results from the REPLACE registry. Circulation 2010;122:1553-61.

81. KinchWesterdahl A, Sjöblom J, Mattiasson AC, Rosenqvist M, Frykman V. Implantable cardioverter-defibrillator therapy before death: high risk for painful shocks at end of life. Circulation 2014;129:422-9.

82. Naksuk N, Saab A, Li JM, Florea V, Akkaya M, Anand IS et al. Incidence of appropriate shock in implantable cardioverter-defibrillator patients with improved ejection fraction. J Card Fail 2013;19:426-30.

83. Sanders GD, Hlatky MA, Owens DK. Cost-effectiveness of implantable cardioverter-defibrillators. N Engl / Med 2005;353:1471-80.

84. Schackman BR, Gold HT, Stone PW, Neumann PJ. How often do sensitivity analyses for economic parameters change cost-utility analysis conclusions? Pharmacoeconomics 2004;22:293-300.

85. Connolly SJ, Hallstrom AP, Cappato R, Schron EB, Kuck KH, Zipes DP et al. Meta-analysis of the implantable cardioverter defibrillator secondary prevention trials. AVID, CASH and CIDS studies. Antiarrhythmics vs implantable defibrillator study. Cardiac Arrest Study Hamburg. Canadian Implantable Defibrillator Study. Eur Heart J 2000;21:2071-8.

86. Poole JE, Johnson GW, Hellkamp AS. Mortality after appropriate and inappropriate shocks in SCD-HeFT (abstract). Heart Rhythm 2006;3:S40.

87. Moss AJ, Greenberg H, Case RB, Zareba W, Hall WJ, Brown MW et al. Long-term clinical course of patients after termination of ventricular tachyarrhythmia by an implanted defibrillator. Circulation 2004;110:3760-5. 
88. Zwanziger J, Hall WJ, Dick AW, Zhao H, Mushlin AI, Hahn RM et al. The cost effectiveness of implantable cardioverter-defibrillators: results from the Multicenter Automatic Defibrillator Implantation Trial (MADIT)-II. J Am Coll Cardiol 2006;47:2310-8.

89. O'Brien BJ, Connolly SJ, Goeree R, Blackhouse G, Willan A, Yee R et al. Cost-effectiveness of the implantable cardioverter-defibrillator: results from the Canadian Implantable Defibrillator Study (CIDS). Circulation 2001;103:1416-21.

90. Noyes K, Corona E, Zwanziger J, Hall WJ, Zhao H, Wang H et al. Health-related quality of life consequences of implantable cardioverter defibrillators: results from MADIT II. Med Care 2007;45:377-85.
91. Hamilton GA, Carroll DL. The effects of age on quality of life in implantable cardioverter defibrillator recipients. / ClinNurs 2004;13:194-200.

92. Nichol G, Stiell IG, Hebert P, Wells GA, Vandemheen K, Laupacis A. What is the quality of life for survivors of cardiac arrest? A prospective study. Acad Emerg Med 1999;6:95-102.

93. Greenspon AJ, PatelJD, Lau E, Ochoa JA, Frisch DR, Ho RT et al. 16-year trends in the infection burden for pacemakers and implantable cardioverter-defibrillators in the United States. J Am CollCardiol 2011;58:1001-6.

\title{
EP CASE EXPRESS
}

\section{Simplified mapping and ablation of a scar-related atrial tachycardia using magnetic resonance imaging tissue characterization}

\author{
Felipe Bisbal*, David Andreu, and Antonio Berruezo \\ Arrhythmia Section, Cardiology Department, Thorax Institute, Hospital Clínic, C/ Villarroel 170-08036, Barcelona, Catalonia, Spain \\ * Corresponding author. Tel: + 3493 2275551; fax: +3493 4513045; E-mail address: f.bisbalvb@gmail.com
}

A 32-year-old woman with atypical atrial flutter was referred for a first-ever ablation. A preprocedural delayed-enhancement cardiac magnetic resonance (DE-CMR) was performed; the three-dimensional reconstruction of left atrium depicting the healthy (purple) and scarred myocardium (red) was imported into the navigation system to guide the ablation. A counterclockwise perimitral activation sequence was identified (panel $A$ ).

The substrate characterization provided by DE-CMR facilitated the identification of an anatomical isthmus at the inferior aspect of the left atrium (panels $B$ and $C$ ), between a large, scarred area at the posterior wall (asterisk) and the inferior mitral annulus (black arrowheads). The integrated DE-CMR reconstruction allowed catheter positioning and limited mapping at this site; a continuous, fractionated signal-highly suggestive of a protected, slow-conducting isthmus-was identified. Radiofrequency application at this site terminated the arrhythmia. No further arrhythmias could be induced.

The standard ablation approach of a perimitral flutter includes extensive ablation at the mitral isthmus to create a line of block; in patients without prior AF ablation, additional encircling lesions around the leftsided pulmonary veins are required. In this case, DE-CMR was crucial in
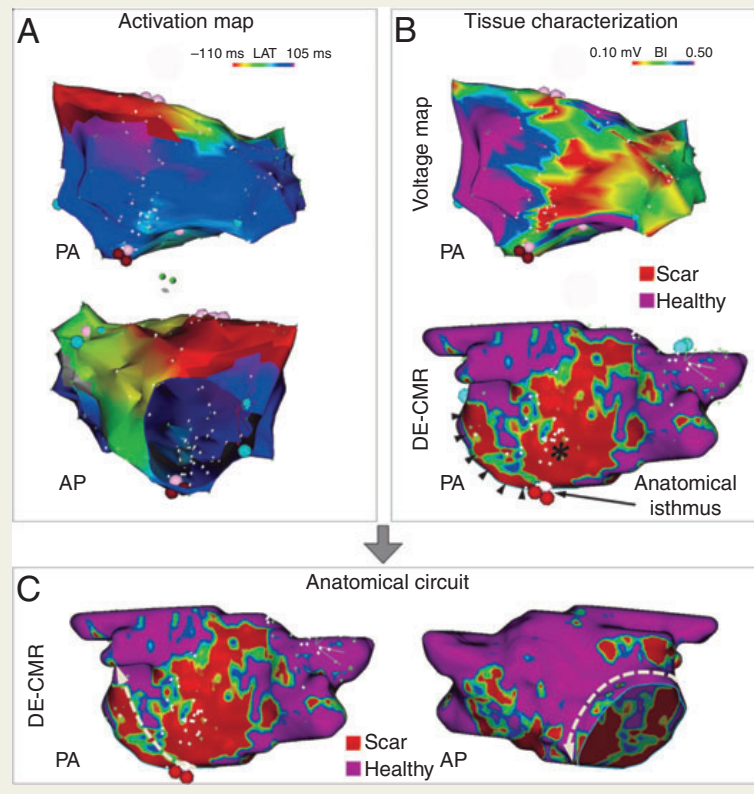

identifying the critical isthmus of the circuit; this allowed limited mapping to the area of interest and limited energy delivery.

The full-length version of this report can be viewed at: http://www.escardio.org/communities/EHRA/publications/ep-case-reports/ Documents/Simplified-mapping-and-ablation.pdf.

Published on behalf of the European Society of Cardiology. All rights reserved. C) The Author 2014. For permissions please email: journals.permissions@oup.com. 